\title{
MOTIVATION AND CONSTRAINTS IN ENGLISH LANGUAGE LEARNING OF ETHNIC MINORITY STUDENTS AT THAI NGUYEN UNIVERSITY OF SCIENCES
}

Nguyen Thi Thao

TNU - University of Sciences

\begin{abstract}
Motivation plays an integral role in the success of learning a new language. However, in some cases, despite having high motivation, learners still find it very challenging to master the language. This is because they may face a lot of constraints in learning the language. This study attempts to figure out the level of English learning motivation of ethnic minority university students as well as the constraints that negatively influence their learning process. Data were collected from the questionnaire with 65 ethnic minority students at Thai Nguyen University of Sciences. The findings show that regardless of many disadvantages related to their living conditions and language knowledge background, ethnic minority students are motivated in learning English. Second, some of the biggest constraints in learning English were investigated, including students' lack of English background knowledge, inappropriate learning strategies, inconfidence in using the language and laziness. Based on the findings, some relevant implications are recommended for the improvement of the teaching and learning environment at the university to create necessary support for learners to develop their English language skills effectively.
\end{abstract}

Key words: education; motivation; constraints; ethnic minority students; English learning.

Received: 11/8/2020; Revised: 15/10/2020; Published: 20/10/2020

\section{ĐÔNG LỬC VÀ CẢN TRỞ TRONG VIÊC HOC TIẾNG ANH CỦA SINH VIÊN DÂN TỘC THIỂU SỐ Ở TRƯỜnG ĐẠI HỌC KHOA HỌC - ĐẠI HỌC THÁI NGUYÊN

\author{
Truoòng Đại học Khoa học - ĐH Thái Nguyên
} \\ Nguyễn Thi Thảo}

\section{TÓM TẮT}

Động lực đóng một vai trò không thể thiếu trong sự thành công của việc học một ngôn ngữ mới. Tuy nhiên, trong một số trường hợp, mặc dù có động lực cao, người học vẫn thấy rất khó khăn để làm chủ ngôn ngữ. Điều này là do người học có thể phải đối mặt với rất nhiều cản trở trong việc học ngôn ngữ. Nghiên cứu này cố gẳng tìm ra mức độ động lực học tiếng Anh của sinh viên đại học dân tộc thiểu số cũng như các rào cản ảnh hưởng tiêu cực đến quá trình học tập của những sinh viên này. Dữ liệu được thu thập từ bảng câu hỏi với 65 sinh viên dân tộc thiểu số tại Trường Đại học Khoa học, Đại học Thái Nguyên. Kết quả khảo sát cho thấy mặc dù có rất nhiều bất lợi liền quan đến điều kiện sống và nền tảng kiến thức ngôn ngữ, sinh viên dân tộc thiểu số có động lực trong việc học tiếng Anh. Thứ hai, một số rào cản lớn nhất trong việc học tiếng Anh được phát hiện, bao gồm sự thiếu kiến thức nền tảng tiếng Anh, chiến lược học tập không phù hợp, sự bất tiện trong việc sử dụng ngôn ngữ và sự lười biếng của bản thân sinh viên. Trên cơ sở các kết quả nghiên cứu, tác giả đã đưa ra một số đề xuất cải thiện các hoạt động giảng dạy và môi trường học tập tiếng Anh tại trường đại học, tạo ra những hỗ trợ cần thiết cho người học có thể phát triển các kỹ năng ngôn ngũ̃ một cách hiệu quả.

Từ khóa: giáo dục; động lục; rào cản; sinh viên dân tộc thiểu số; học tiếng Anh.

Ngày nhận bài: 11/8/2020; Ngày hoàn thiện: 15/10/2020; Ngày đăng: 20/10/2020

Email:thaont@tnus.edu.vn

DOI: https://doi.org/10.34238/tnu-jst.3484 


\section{Introduction}

\subsection{Research rationales}

English is considered the most popular language in the integration and globalization process. Especially, English has become the lingua franca in many important fields such as business, politics, sciences, technology, and entertainment. In recent decades, more and more foreign companies and organizations have invested in Vietnam, making the demand for English use that has increased and creating better job opportunities for students who are good at this language.

In Vietnam, English has been introduced in the national education system as a foreign language since the 1990s. However, the progress of teaching and learning English is different among rural and urban areas, low land and mountainous areas; thus, the abilities to use English language are unequal among regions. In fact, ethnic minority groups living in the rural mountainous areas have fewer opportunities and conditions to practice and use modern equipment in studying English in comparison with students in the urban and lowland areas. Therefore, teaching English to this group of students has never been an ease to English lecturers.

Thai Nguyen University of Sciences (TNUS), located in midland and mountainous regions in northern Vietnam, has over $65 \%$ of students coming from more than 10 minority ethnic groups. Almost all of these students have their own ethnic languages, so English could be their third language (besides Vietnamese and their mother ethnic tongue). Thus, ethnic minority students at TNUS have more disadvantages in English study causing limitations in job opportunities after graduation. Promoting motivations and reducing constraints in English learning are necessary contributions to improve the ability of using the language of minority ethnic students at the university. This research investigated motivations and constraints of ethnic minority students and their expectation in learning English at the TNUS with the aim of assessing English learning motivations and constraints to deliver relevant suggestions of English learning improvement.

\subsection{Literature review}

\subsubsection{Definition of motivation}

Motivation is the most important factor in second language acquisition and is understood in various ways in the field of language learning. Chilingaryan and Gorbatenko defined motivation as a thing that can increase students' determination and interest in language learning. They also explained that motivation is "a desire to achieve a goal, combined with the energy to work towards that goal" [1]. Alizadeh [2] thought that motivation was 'a key factor for explaining the success or failure of any difficult activity'. She also showed that in learning English as a foreign language, motivation provided learners with an aim and direction to follow [2]. According to Lightbown and Spada [3], motivation in second language learning included two factors: learner's communicative needs and their attitudes towards the second language community. Besides, motivation is the combination of attempt plus desire to obtain the aim of learning the language plus favorable attitudes toward learning the language [2], [4]. Sharing the same idea, Ellliot and Covington considered motivation as the reasons for people's actions, desires, and needs [5]. Thus, it is obvious that motivation is crucial in the process of English language learning. Without it, learners would not be able to master a language despite a variety of teaching methods applied by teachers or the amount of investment paid by their parents.

\subsubsection{Types of motivation}

Motivation can be classified into various categories as follows: (1) short-term goal (a wish of succeeding in doing something in the near future like passing their examination or 
getting high scores) and long-term goal (a desire of getting a better job in the future or to be able to communicate with the native speakers of the language) [6]; (2) intrinsic motivation (engaging in an activity being enjoyable to do) and extrinsic motivation (the actions that are performed to get some instrumental aims) [7], or (3) integrative (language learning for personal growth and cultural enrichment) and instrumental (language learning for functional and external reasons) [7], [8].

Integrative motivation is defined as the desire to be a part of recognized or important members of the community or the society that speaks the second language. It refers to the interest in learning the second language because of their need to learn about, associate or socialize with the people who use it or because of purpose or intention to participate in or integrate into the community using that language; but sometimes it involves emotion or affective factors as well [9].

Instrumental motivation mainly focuses on purely practical value in learning the second language in order to increase learners' careers or business opportunities, give them more prestige and power, access scientific and technical information, or just pass a course of their study [9].

\subsubsection{Constraints in learning English}

Constraints in learning can be understood as something that limits or controls what learners can do. Sometimes, it is thought as something that limits the freedom to do what people want. A research of Edwards in 2014 showed that during the second language learning, learners' acquisition is shaped by both language-internal and language-external constraints [10]. Language-internal constraints refer to both negative and positive roles of the previous language. Language-external constraints are factors beyond linguistic influences which are often called "social factors". The social factors include opportunities, learning environment, willingness, and ability of the learners to acquire and use the second language [10], [11]. Because the object of this study is university students, we analyzed the motivation based on integrative and instrumental classification and social constraints in English learning as foreign language at TNUS. The constraints were approached based on aspects from learners such as background English knowledge and skills; learning strategies and from outsiders such as the learning environment and facilities; teaching methodology. The following sections of this article will describe methodology of data collection and analysis. After that, in the research results, the researchers focused on assessment and discussion of motivations and constraints in English language learning, from those some suggestions are proposed to improve the English learning of ethnic minority students at TNUS.

\section{Methodology}

The research uses the descriptive method to find out students' motivations for learning English and constraints in their learning. The indicators of motivation and constraints were selected based on literature review and the real context at the TNUS. The data were collected by a questionnaire. The questionnaire was designed with 3 parts including (1) background information of respondents with 11 questions; (2) motivations of English language learning with 13 indicators; (3) constraints of English language learning with 13 indicators. Background information of respondents supports the descriptive analysis of impact factors in English study (both motivation and constraints). The Likert scale was used to assess 5 levels of motivations and constraints in English study from totally disagreeing to totally agreeing with each suggested indicator.

An online survey was delivered randomly to 100 ethnic minority students at TNUS in April 2020. The researchers received the feedback of 65 ethnic minority students at 
TNUS who are studying in different faculties from the 1 st to 4 th year. The data were coded and analyzed on excel software. The results were described statistically using percentage and frequency. The interviewees' assessment of motivations and constraints were calculated into mean values with the aim of comparing the assessment level among indicators.

\section{Results and discussion}

\subsection{Respondents' information}

The survey was delivered to 65 students of different faculties at TNUS, in which $64.6 \%$ are male and $35.6 \%$ are female. Their ages range from 18 to 25 , the common ages of university students in Vietnam. Nearly a half of respondents (46.2\%) are 1st-academic-year students. The number of students studying in the first, second and fourth academic year are $16.9 \%, 6.2 \%$, and $30.8 \%$ respectively.

Most students come from rural and remote mountainous areas $(43.1 \%$ and $47.7 \%$ respectively), and only $9.2 \%$ of students live in urban areas. Particularly, these 65 students come from 12 different minor ethnic groups (Figure 1), in which Tay and H'mong ethnic groups occupied for more than half of respondents, followed by Dao and Nung ethnic groups with $12 \%$ and $11 \%$ respectively while $12 \%$ of remaining respondents are other ethnic minority groups namely Thai, Muong, Ha Nhi, Giay, La Ha, Cao Lan, San Diu, San Chi and La Hu. Regarding family socio-economic background of the respondents, the data revealed that most of the students came from farming families, taking up to $86.2 \%$. Significantly, more than a half of families
$(53.8 \%)$ earned less than 3 million VND per month (Table 1).

In terms of pre-college English level of students, nearly a half of students (49.2\%) confirmed that they had learnt English for more than 7 years and $43.1 \%$ spent 4 to 7 years learning English before university. However, more than $60 \%$ of respondents got low and very low scores (below 5 points) at the national high school graduation examination. The rate of respondents had good and very good marks (from 6.5 to 10 points) in that exams occupied less than $10 \%$ (Table 2).

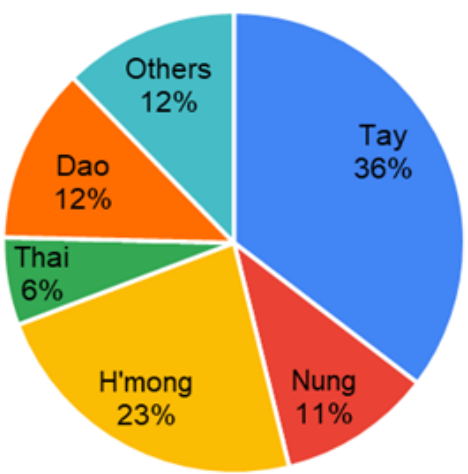

Figure 1. Ethnicity distribution of respondents

Table 1. Family's socio-economic background of respondents

\begin{tabular}{lr}
\hline Parents' occupations & \% \\
\hline Farmers & 86.2 \\
Governmental officers & 10.7 \\
Businessmen & 3.1 \\
\hline Family's income & \\
\hline Less than 3 million VND & 53.8 \\
Between 3-5 million VND & 21.5 \\
Between 5-7 million VND & 15.4 \\
Over 7 million VND & 9.3 \\
\hline
\end{tabular}

Table 2: Pre-university English level of respondents

\begin{tabular}{|c|c|c|c|c|}
\hline \multirow{2}{*}{\multicolumn{2}{|c|}{$\begin{array}{l}\text { No. of years spending } \\
\text { learning English }\end{array}$}} & \multicolumn{3}{|c|}{ English score at the national high school graduation exam } \\
\hline & & \multirow{2}{*}{$\begin{array}{c}\text { Points } \\
8.0-10.0\end{array}$} & \multirow{2}{*}{\begin{tabular}{|c|} 
Grade \\
Very good
\end{tabular}} & \multirow{2}{*}{$\begin{array}{c}\text { Percentage } \\
1.5\end{array}$} \\
\hline $1-3$ years & $7.7 \%$ & & & \\
\hline 4-7 years & $43.1 \%$ & $6.5-7.5$ & Good & 6.2 \\
\hline \multirow[t]{3}{*}{$>7$ years } & $49.2 \%$ & $5.0-6.5$ & Fair & 29.2 \\
\hline & & $3.5-4.5$ & Low & 40.0 \\
\hline & & $<3.5$ & Very low & 23.1 \\
\hline
\end{tabular}


Table 3. Motivation assessment of students in learning English

\begin{tabular}{|c|c|c|c|c|c|c|c|}
\hline \multirow{2}{*}{$\begin{array}{l}\text { Motivational } \\
\text { constructs }\end{array}$} & \multirow{2}{*}{ I want to learn English because ... } & \multicolumn{5}{|c|}{ Assessment scales (\%) } & \multirow{2}{*}{ Mean } \\
\hline & & 1 & 2 & 3 & 4 & 5 & \\
\hline \multirow{6}{*}{$\begin{array}{l}\text { Instrumental } \\
\text { motivation }\end{array}$} & English helps me find a good job & 4.5 & 0.0 & 1.5 & 51.0 & 43.0 & 4.28 \\
\hline & I want to enhance my academic result & 3.1 & 3.1 & 10.8 & 61.5 & 21.5 & 3.92 \\
\hline & English is necessary to travel abroad & 1.5 & 7.7 & 15.4 & 52.3 & 23.1 & 3.86 \\
\hline & It's necessary to my higher education & 4.6 & 6.2 & 15.4 & 53.8 & 20.0 & 3.75 \\
\hline & it's a compulsory subject at the university & 9.2 & 10.8 & 20.0 & 44.6 & 15.4 & 3.40 \\
\hline & I want to study abroad & 4.6 & 12.3 & 33.8 & 38.5 & 10.8 & 3.38 \\
\hline \multirow{7}{*}{$\begin{array}{l}\text { Integrative } \\
\text { motivation }\end{array}$} & $\begin{array}{l}\text { I want to be an open, confident and social } \\
\text { person like English speaking people. }\end{array}$ & 3.0 & 1.5 & 10.7 & 52.3 & 32.3 & 4.09 \\
\hline & I want to communicate with foreigners. & 3.1 & 3.1 & 7.7 & 56.9 & 29.2 & 4.06 \\
\hline & $\begin{array}{l}\text { I want to introduce Vietnamese cultures to } \\
\text { foreigners. }\end{array}$ & 3.1 & 3.1 & 15.4 & 49.2 & 29.2 & 3.97 \\
\hline & $\begin{array}{l}\text { I want to investigate about the lives and } \\
\text { cultures of English-speaking people. }\end{array}$ & 1.5 & 0.0 & 21.5 & 60.0 & 17.0 & 3.88 \\
\hline & $\begin{array}{l}\text { I want to participate in academic, social } \\
\text { and professional activities among people } \\
\text { from different countries }\end{array}$ & 3.1 & 3.1 & 20.0 & 50.8 & 23.0 & 3.88 \\
\hline & $\begin{array}{l}\text { I want to read books, watch movies and } \\
\text { listen to music in English }\end{array}$ & 3.1 & 4.5 & 15.4 & 60.0 & 20.0 & 3.86 \\
\hline & $\begin{array}{l}\text { I want my friends and other people } \\
\text { respect me. }\end{array}$ & 7.7 & 10.8 & 29.2 & 43.1 & 9.2 & 3.35 \\
\hline
\end{tabular}

Note: 5 = strongly agree $; 4$ = agree $; 3=$ neutral; 2 = disagree $; 1=$ strongly disagree

\subsection{Motivations in learning English}

The motivations in learning English include 6 instrumental and 7 integrative motivation indicators (Table 3).

In term of instrumental motivations, the most motivation of English studying is it helps them find a good job (43\% of participants strongly agreed, $51 \%$ agreed), which followed by the reason of having a good academic result with $83 \%$ agreements in total. Abroad travelling and learning English for higher education stand the third and fourth positions in instrumental motivation in learning English of ethnic students at TNUS when over $70 \%$ of respondents agreed with two these motivations. The compulsory subject at the university and studying abroad are at the lower motivation levels in this group. It is the fact that English language is compulsory in all bachelor programs at TNUS with $13 / 135$ credits. Thus, getting good marks in English modules will contribute to the overall academic results of each students. Moreover, using English fluently will widen opportunities to apply for good jobs and positions, especially in the modernization and globalization process nowadays.

In the group of integrative motivations, students were highly motivated on all the mentioned. Most students claimed that they wanted to learn English to be an open, confident and social person like English speaking people (32.3\% strongly agreed and $52.3 \%$ agreed) or to be able to communicate with foreigners (29.2\% strongly agreed and $56.9 \%$ agreed). Besides, many of them also agreed that they learned English because they wanted to investigate about the lives and cultures of English speaking people (17\% strongly agreed and 60\% agreed), introduce Vietnamese cultures to foreigners $(29 \%$ strongly agreed and $49 \%$ agreed), participate in academic, social and professional activities among people from different countries $(22 \%$ strongly agreed and 51\% agreed), and read books and watch movies and listen to music 
in English (20\% strongly agreed and 57\% agreed). Having respect from other people was also highly admitted to be the motivation of learning English by $52 \%$ of respondents.

Overall, the respondents possessed all of these motivations; however, the level of motivation is not highly assessed with the evidence that mean values ranged from 3.35 to 4.28 , in which integrative motivation was stronger than the instrumental one.

\subsection{Constraints in learning English}

Constraint assessment results of the ethnic minority students in learning English were illustrated in Table 4. Constraints originated from learners are coded from $\mathrm{C} 1$ to $\mathrm{C} 7$ in the table. $\mathrm{C} 8$ to $\mathrm{C} 14$ are constraints originated from outsiders (could be from teachers, university's facilities or communicative environment).

In a group of constraints from learners themselves (C1 to $\mathrm{C} 7$ ), the survey data showed that inappropriate learning strategies were the biggest constraints of students when about $23 \%$ of the students strongly agreed and $66.2 \%$ agreed that they did not have a proper learning strategies. With regard to background knowledge, many students admitted that their poor background knowledge and skills such as vocabulary, grammar and pronunciation were the constraints in learning English. For example, over $80 \%$ of the respondents agreed that their limitations of vocabulary and grammar negatively affected their learning English while only nearly $7 \%$ of respondents disagreed with these points. Although the number of students agreeing that their poor pronunciation was a constraint was lower than the number of students who considered their poor vocabulary and grammar as their constraints, the proportion still accounted over $60 \%$. These statistic data matched with their feedback of their worst skills in English learning. The low pre-university English level (showed in Table 2) is one of reasons for constraints relating to poor English knowledge and skills of these interviewed students. Poor English knowledge made students feel unconfident and this became a main constraint (C5) in their language study.

Table 4. Constraint assessment of students in learning English

\begin{tabular}{llccccccc}
\hline \multirow{2}{*}{ Code } & \multicolumn{1}{c}{ Constraints } & \multicolumn{3}{c}{ Assessment scale $(\%)$} & \multirow{2}{*}{ Mean } \\
& & $\mathbf{1}$ & $\mathbf{2}$ & $\mathbf{3}$ & $\mathbf{4}$ & $\mathbf{5}$ & \\
\hline C1 & My learning strategies/methods are not appropriate. & 1.5 & 4.6 & 4.6 & 66.2 & 23.1 & 4.05 \\
C2 & My vocabulary is poor. & 4.6 & 3.1 & 9.2 & 61.5 & 21.5 & 3.92 \\
C3 & My grammar is poor. & 0.0 & 4.6 & 12.3 & 72.3 & 10.8 & 3.89 \\
C4 & I am too lazy to learn English. & 0.0 & 6.2 & 16.9 & 40 & 15.4 & 3.86 \\
C5 & I am not confident enough to use the language in & 4.6 & 9.2 & 7.7 & 60.0 & 15.4 & 3.72 \\
& communication. & 3.1 & 4.6 & 23.1 & 60.0 & 1.5 & 3.68 \\
C6 & My pronunciation is poor. & 7.6 & 38.5 & 38.5 & 12.3 & 3.1 & 2.65 \\
C7 & I am not interested in learning English. & 3.1 & 9.2 & 29.2 & 41.5 & 16.9 & 3.60 \\
C8 & I don't have the language environment to practice & 3.1 & 18.5 & 26.1 & 35.4 & 16.9 & 3.45 \\
& the language. & 3.1 & 23.1 & 41.5 & 24.6 & 7.7 & 3.11 \\
C9 & My financial resources are insufficient. & 9.2 & 23.1 & 35.4 & 23.1 & 9.2 & 3.00 \\
C10 & The teaching hours for English are inadequate. & 3.1 & 33.8 & 41.5 & 18.5 & 3.1 & 2.85 \\
C11 & The class is crowded. & 4.6 & 32.3 & 41.5 & 16.9 & 4.6 & 2.85 \\
C12 & The English textbooks are not interesting. & & \\
C13 & Teaching methods at the university are boring. & & & &
\end{tabular}

Note: 5 = strongly agree $; 4$ = agree $; 3$ = neutral; 2 = disagree $; 1=$ strongly disagree 
English learning interest had lowest agreement level of students in all of suggested constraints in the survey with mean value under 3. It means that interest is not their constraint in English learning. Although the group of self-learner constraints was assessed at a higher level than the outsider's constraint group, nearly $70 \%$ of students confirmed that one of constraints in learning English was their laziness.

In a group of constraints originated outsiders (C8 to C13), lack of practical English environment received more agreement from two third of interviewees. This constraint is partly related to geography, position and socio-economic conditions of Thai Nguyen province where TNUS is located. Although Thai Nguyen borders Hanoi capital, there are not many English-speaking foreigners working and visiting there. Additionally, TNUS has not got any international education program in the English language; thus, students lack chances to communicate directly with foreigners as students in some big and tourism provinces in Vietnam. Moreover, most of respondents come from rural and mountainous areas where there is a lack of the supportive environment for English practice.

More than $50 \%$ of interviewed students claimed that they had insufficient financial resources to take English courses in foreign language centers or buy laptops, books and materials which support for English learning outside the university (C9). This can be understood because up to $87 \%$ of these students come from farming families and more than a half of their families have income below 3 million VND. Unal and Ilhan (2017) illustrated in their research that little contact with foreign language speakers and lack of support outside class were constraints in English learning in Turkey [11].

Factors on sides of the university such as inadequate teaching hours (C10) and crowded class (C11) were considered constraints in learning English but the assessment stood at low level with one third of interviewees' agreement of each factor. Boring textbooks and teaching methods received the lowest agreements in all of these constraint groups. However, less than $40 \%$ of the students agreed and totally agreed that these were not their constraints. In fact, in Vietnam not only students but English teachers also face similar constraints [12].

\subsection{Proposal solutions to improve English learning at the university}

The survey results showed that ethnic minority students were motivated to study the English language, but they lacked suitable learning conditions, methods and strategies. Thus, they need the encouragement and support of suitable learning strategies to improve their English language from English teachers, university administrators or classmates. To promote English learning quality in the university, the researchers propose some suggestions for university administrators and English teachers.

Students should take an exam to classify them at the first semester. The students having worse results should be provided an extra English course which aims to provide this group of students with very basic English knowledge and skills.

Students have a strong desire to learn English, but they do not know how to start or to make strides in learning. Thus, together with teaching, English lecturers should give more discussion on how to learn English effectively and provide popular English learning websites, which may be integral to the students' success in learning the language.

The university should provide a learning environment such as well-equipped language laboratories, English club and opportunities for students to go abroad so that students have opportunities to practice and use English. The 
English club creates a real and relaxing language environment for students so that they can communicate in English without any fear. Moreover, during club meetings, better English speakers could support worse ones. Internship and exchange student programs in the foreign partnership universities are also good opportunities and motivations for students in language learning.

Finally, related to teaching methods, teachers should be flexible in applying different teaching techniques that suit the students' needs. They should utilize various communicative activities and audio-visual materials in the classroom when teaching students with different backgrounds and levels of English like this target student group. Pair work and group work activities should be more frequently organized to create and increase a relaxing learning environment.

\section{Conclusion}

The ethnic minority students at TNUS had quite strong desire in learning English. Among types of motivation, their integrative motivation was higher appreciated than instrumental one. Finding a good job, changing themselves and communicating with foreigners are three motivations receiving the most agreements of this target student group. However, they have a lot of constraints in learning English as a foreign language, especially constraints on the side of learners. These constraints are related their personal and family background because most of them comes from low-income farming families in rural and mountainous areas. They also have a low English background level before university studying. Although the constraints come from outsiders received lower evaluation by respondents, it is still necessary and useful for researchers to recommend university administrators and English teachers to enhance the quality of English language learning at the university.

\section{REFERENCES}

[1]. K. Chilingaryan and R. Gorbatenko, "Motivation in language learning," In Proc. 2nd International Multidisciplinary Scientific Conference on Social Sciences and Arts, RUDN University, pp. 661 - 672, 2015.

[2]. M. Alizadeh, "The Impact of Motivation on English Language Learning," International Journal of Research in English Education, vol. 1, no. 1, pp.11-15, 2016. [Online]. Available: http://ijreeonline.com/browse.php? a_code=A-10-1-3\& [Accessed May 10, 2020].

[3]. P. M. Lightbown and N. Spada, How languages are learned. Oxford University, England, 1999.

[4]. R. C. Gardner, Social Psychology in Second Language Learning. Edward Arnold Ltd, London, Great Britain, 1985.

[5]. A. J. Elliot and M.V. Covington, "Approach and Avoidance Motivation," Educational Psychology Review, vol 13, no. 2, pp.73-92, 2001. [Online]. Available: https://link.springer.com/article/10.1023/A:10 09009018235 [Accessed May 10, 2020].

[6]. J. Harmer, The practice of English language teaching. Longman, London, England, 1991.

[7]. S. Khasinah, "Factors influencing second language acquisition," Journal of Englisia, vol.1 no.2. pp. 256-269, 2014.

[8]. B. H. Douglas, Principles of Language Learning and Teaching, 4th ed. Addison Wesley Longman, New York, 2000.

[9]. M. Saville-Troike, Introducing second language acquisition. Cambridge University Press, New York, 2006.

[10]. J. G. H. Edwards, "Developmental sequences and constraints in second language phonological acquisition: Balancing language-internal and language-external factors," In Social Dynamics in Second Language Accent, J. Levis and A. Moyer Eds. Boston/Berlin: De Gruyter Mouton, 2014, pp. 53-73.

[11]. M. Unal and E. Ilhan, "A Case Study on the Problems and Suggestions in Foreign Language Teaching and Learning at Higher Education," Journal of Education and Training Studies, vol. 5, no. 6, pp. $64-72,2017$.

[12]. L. H. N. Phan, "Challenges/constraints in teaching today's English in Vietnam: Teachers' voices," in Proceeding of $8^{\text {th }}$ Annual International Conference on TESOL, 2017, pp.1-8. 